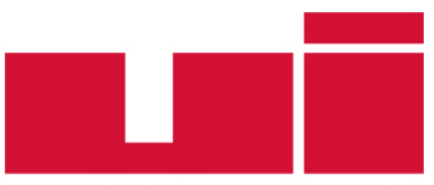

ULLUSLARARASTiLiŞKiLER

Akademik Dergi

Yayın ilkeleri, izinler ve abonelik hakkında ayrıntılı bilgi:

E-mail: bilgi@uidergisi.com.tr

Web: www.uidergisi.com.tr

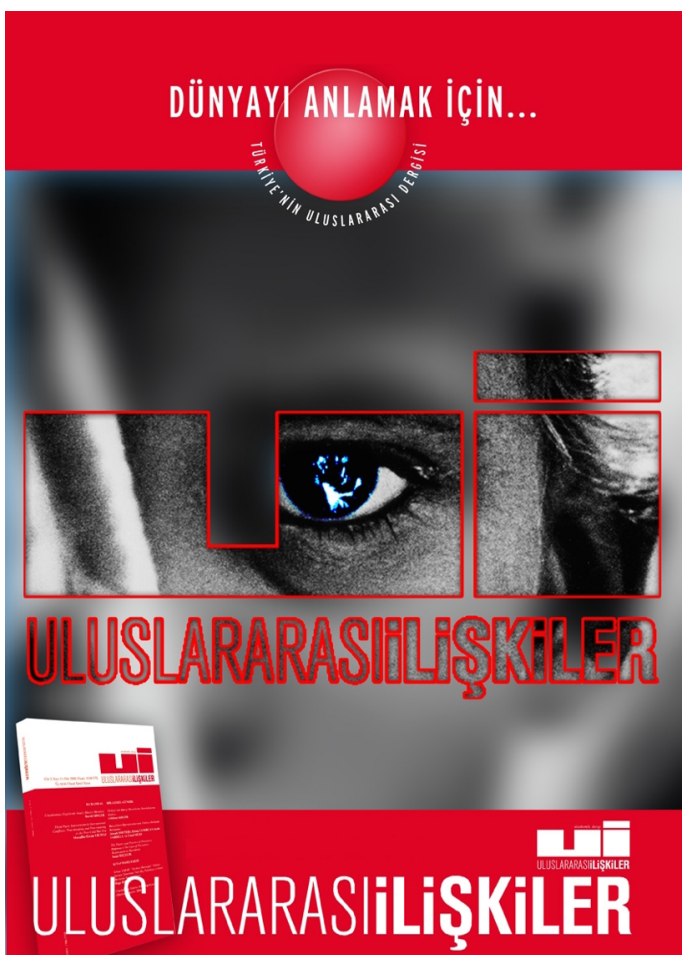

\title{
Aydınlanma Döneminden Günümüze Bilimsel Bilginin Temelindeki Ana Sorunsal: İdealizm-Materyalizm Tartışması ve Diyalektik Yöntem
}

\section{Ekin Oyan ALTUNTAŞ*}

* Yrd. Doç. Dr., Abant İzzet Baysal Üniversitesi, Uluslararası İlişkiler Bölümü

Bu makaleye atıf için: Altuntaş, Ekin Oyan, "Aydınlanma Döneminden Günümüze Bilimsel Bilginin Temelindeki Ana Sorunsal: İdealizm-Materyalizm Tartışması ve Diyalektik Yöntem”, Uluslararası İlişkiler, Cilt 12, Sayı 47, s. 27-43.

Bu makalenin tüm hakları Uluslararası İlişkiler Konseyi Derneği’ne aittir. Önceden yazılı izin alınmadan hiç bir iletişim, kopyalama ya da yayın sistemi kullanılarak yeniden yayımlanamaz, çoğaltılamaz, dağıtılamaz, satılamaz veya herhangi bir şekilde kamunun ücretli/ücretsiz kullanımına sunulamaz. Akademik ve haber amaçlı kısa alıntılar bu kuralın dışındadır.

Aksi belirtilmediği sürece Uluslararası Illişkiler'de yayınlanan yazılarda belirtilen fikirler yalnızca yazarına/yazarlarına aittir. UİK Derneğini, editörleri ve diğer yazarları bağlamaz.

Uluslararası İlişkiler Konseyi Derneği | Uluslararası İlişkiler Dergisi

Web: www.uidergisi.com.tr | E- Posta: bilgi@uidergisi.com.tr 


\title{
Aydınlanma Döneminden Günümüze Bilimsel Bilginin Temelindeki Ana Sorunsal: İdealizm-Materyalizm Tartışması ve Diyalektik Yöntem
}

\author{
Ekin Oyan ALTUNTAŞ \\ Yrd. Doç. Dr., Uluslararası İlişkiler Bölümü, İIBF, Abant İzzet Baysal Üniversitesi, Bolu. \\ E-posta: oekinoy@yahoo.com.tr
}

\section{ÖZET}

Gerçekliğe ilişkin bilginin nereden kaynaklandığı ve bu bilgiye nasıl ulaşılacağı felsefeye ait bir tartışma alanı gibi görünmektedir. Bununla birlikte, günümüzde sosyal bilimler alanında çalışma yapan bilim insanları farkında olarak veya olmayarak bu soruya yanıt arayan iki farklı paradigma olan İdealizm ve Materyalizm içinden bilgi üretmektedir. Bu iki paradigma ve iç türevleri dışında bilgiye ulaşma yönteminde ana ayrım diyalektik yaklaşıma sahip olup olmamakla ortaya çıkmaktadır ki, bu ayrım bilginin bilimsel olup olmadığının başlıca belirleyicisidir. Bu çalışmanın amacı, sosyal bilimlerdeki idealist-materyalist ayrışmasının genel eğilimlerini ve diyalektik anlayışın süreçteki rolünü Aydınlanma döneminden günümüze kadar devam eden süreç içinde öne çıkan kuramlar bağlamında analiz etmek ve 1900'lerden günümüze kapitalist üretim ilişkilerinde yaşanan dönüşümlerin gerçekliğin tanımına ilişkin teorik yaklaşımları nasıl bilimsellikten uzaklaşarak salt öznenin bilinci veya öznesiz ilişkiler ağına indirgediğini eleştirel bir şekilde değerlendirmektir.

Anahtar Kelimeler: Hegel, Marx, Felsefe, Varlık, Bilinç, Postmodernizm

\section{The Fundamental Question Underlying Scientific Knowledge since the Age of Enlightenment: Idealism versus Materialism Debate and the Dialectical Method}

\begin{abstract}
It appears that where knowledge about reality originates from and how one can reach that knowledge is a topic to be discussed within philosophy. On the other hand, scientists who are doing research in social sciences are, either knowingly or unknowingly, producing knowledge within Idealism and Materialism, which are two paradigms searching for an answer to this question. The main distinction in the method used to reach knowledge, except for the ones in these two paradigms and their internal derivatives, emerges according to whether a dialectical approach is utilized, and this distinction is the main determiner of whether knowledge is scientific or not. The aim of this study is to analyze the general inclinations of the idealist-materialist distinction in social sciences and the role of the dialectical approach used in this process in line with the institutions that have stood out from the Age of Enlightenment up to this date. The study also aims to criticize the consequences of transformations in capitalist accumulation model throughout 1900s and their effects on theoretical approaches which become distant to scientific understanding and define reality just in accordance with human consciousness or post-human social network system.
\end{abstract}

Keywords: Hegel, Marx, Philosophy, Entity, Consciousness, Postmodernism 


\section{Giriş}

Varlığın gerçekliğinin ne olduğu ve bu bilgiye nasıl ulaşılacağına ilişkin tartışma sosyal bilimler içesinde hiçbir zaman güncelliğini yitirmemiştir. Bu tartışmanın tek bir esaslı soru üzerinden türevlendiğini iddia etmek, sorunu oldukça dar bir kalıba sokmak anlamına gelmekle birlikte, sorunu anlaşılır kılmaktadır. Sorunun özü nesne ile öznenin birbirlerinden bağımsız süreçlerin ürünü olup olmadıkları üzerinden başlamakta ve daha sonra gerçekliğin kendisini üreten unsurların süregiden süreçte birbirlerini dışlayarak mı, özdeşleştirerek mi yoksa koşullandırarak mı var oldukları konusuna gelip dayanmaktadır. $\mathrm{Bu}$ ana sorunun cevabı ikincil bir soruyu da hemen peşi sıra gündeme getirmektedir. Gerçekliğin kendisine zihinsel-bilinç (idealist) temelli olarak mı yoksa maddeci-varlık (materyalist) temelli bir yaklaşımla mı ulaşılabilir?

Olgu ve olayları açıklama, bunların toplumsal bağlarını ortaya çıkartma, aralarındaki ilişkinin nedensellik (içsel ilişkiler-çelişkiler-etkileşim-süreç) sürecini analiz etme ve varılan sonuçları genelleştirerek tutarlı bir bütünsellik içinde açılama ve öngörü oluşmasını sağlama bilimin temel işlevidir. İdealizm ve materyalizm ayrışması ise daha ilk aşamada başlamakta ve olguları açıklama düzeyinde farklı yollara sapmaktadır. Öte yandan, bu tartışmanın içine konulacak olmazsa olmaz koşul, diyalektiğin kendisinin tanımıdır ki bilimsel bilgi üretmenin ilk aşaması olan olguların açıklanması bu tanımın nasıl yapıldığına göre şekillenmektedir.

Bilgiye ulaşma yöntemi ile bilginin kendisi arasında ayrılmaz bir bağ vardır ve bilimsellik epistemoloji-ontoloji birliği ile kanıtlanabilir. Başka bir deyişle, bilgiye ulaşma yöntemi ile ortaya çıkan sonuç çelişkili olmamalıdır. Örneğin, gerçekliğe ulaşma yöntemi veya olgular öznellik, bireysel bilinç, görelilik, ahlak, kimlik veya insani değerler üzerinden açıklanıyor ama nedensellik ilişkisi nesnel tarihsel ve maddi koşullara göre kuruluyorsa ortaya çıkacak sonucun tutarlı ve evrensel bilgi olması, hele hele bilimsel olması beklenmemelidir. Zaten böyle bir durumda çalışma kendi içinde çelişkiye düşmemek için nedensellik bağlantısını olgular arasındaki ilişkiyi bulmak üzere değil, olguların açıklanış yöntemini kanıtlamak üzere kullanacaktır. Akademik zorlama ile başarılan bu bilgi üretimi, sorunun kendisini tespit edebilse dahi açıklama ve nedensellik ilişkisini kurma aşamalarından geçemeyecek ve hiçlikle sonuçlanacaktır.

Tüm bu bilgiler ışığında, süregiden idealist-materyalist ayrışması ve diyalektik anlayışa sahip olmak ve olmamak bir yaklaşım farkı olmanın ötesinde, bilimsel olmak veya hiçlikle sonuçlanmak arasında bir ayrımdır. Öte yandan, uzun yıllar süregiden tartışmalar sonucunda idealist-materyalist ayrışması (özünde aynı kalmakla birlikte) bir dizi gelişme evresinden geçmiş ve farklı kavramlar içinden ifade edilir olmuştur. Günümüzde sosyal bilimler alanı içinde çalışma yapan tüm bilim insanları, farkında olarak veya olmayarak, bu iki farklı paradigma içinden bilgi üretmektedir. $\mathrm{Bu}$ çalışmanın genel amacı, sosyal bilimlerdeki idealist-materyalist ayrışmasının genel eğilimlerini ve diyalektik anlayışın süreçteki rolünü Aydınlanma döneminden günümüze kadar devam eden süreç içinde analiz etmektir. Çalışmanın özel amacı ise diyalektik materyalizmi salt bir yöntem olarak ele almaktan ziyade gerçekliği ortaya çıkartan tarihsel süreçleri, toplumsal ilişkileri, değişimleri, çelişkileri ve bugünü yaratan önkoşulları, "kuram ile uygulamanın dinamik birliği” içinde açıklayan en kapsamlı ve bilimsel düşünme biçimi olduğunu ortaya koymaktır. Buna ek olarak çalışmanın amacı, diyalektik materyalizm perspektifinden 1900'lerden günümüze kapitalist üretim ilişkilerinde yaşanan dönüşümlerin gerçekliğin tanımına ilişkin teorik yaklaşımları nasıl bilimsellikten uzaklaşarak salt öznenin bilinci veya öznesiz ilişkiler ağına indirgediğini eleştirel bir şekilde değerlendirmektir. $\mathrm{Bu}$ bakımdan çalışma, sosyal bilimlerin temelindeki en önemli ayrışma olan ama günümüzde çok dar bir alana hapsolmuş idealizm-materyalizm tartışmasına bir giriş yapmak niyetindedir. 


\section{Aydınlanma Dönemi İdealizm ve Materyalizm Tartışmaları ve Diyalektiğin Sistemleştirilmesi}

Diyalektik yöntemin Friedrich Hegel (1770-1831) tarafından sistemli bir hale getirilerek nesnel idealizme ulaşılmasının öncesinde, bilgiye ulaşma yöntemi konusundaki tartışmalar iki ana gruba ayrılmaktaydı. İlk grupta, doğuştan bilen bilinçli öznenin (öznel idealizm) "zihinsel sezgi” (düşüncenin duyumdan önce oluşması) ile bilgiye ulaştığı, başka bir deyişle bağımsız değişkenin özne olduğu iddiası yer alırken, ikinci grupta duyumları aracılığıyla deneyimleyerek (düşüncenin duyumdan sonra gelmesi) öğrenen özne ve bağımsız değişken olarak madde (ampiristler) üzerine yoğunlaşılmıştır. ${ }^{1}$

Feodal üretim biçiminin çöküşe geçtiği ve özellikle 16. yüzyıldan itibaren doğa bilimlerindeki hızlı gelişimle (özellikle ticari kapitalizmin ihtiyaç duyduğu teknolojik gelişmelerle) feodalitenin üstyapısal meşruiyet kaynağı olan Kilise dogmalarının sorgulanmaya başlandığı bir dönemde, skolastik felsefeden kopuş yaşanmaya başlanmıştır. Bu dönüşüm döneminde modern felsefenin kurucusu kabul edilen Rene Descartes (1596-1650) öznel idealizmin en önde gelen düşünürü olmuştur. Tüm yeniliklerine karşın, öznel idealizmin temelleri Platon ve Aristoteles'ten gelmektedir. İlginç olan, antik Yunan'da idealist görüşün adı geçen düşünürlerle birlikte yükselişe geçmesi de, Yunan toplumunun temeli olan köle ekonomisinin çöküşe geçtiği ve düşünsel anlamda dönüşümün yaşandığı döneme denk geliyor olmasıdır. ${ }^{2}$ Bilginin (hakikatin) kaynağı olarak, bilen ve düşünen ruhu öne çıkartan ve buna ek olarak, aklın üstünlüğünü her şeyin önüne koyan (yönetim her zaman akıllı ve bilge kişilerin elinde olmalıdır) Yunan idealistleri tam da bu dönemin "toplumsal durumunu idealleştirmek ve iç çelişkilerini görünmez kılmak” bakımından egemen sınıfın çıkarlarını yansıtmaktadırlar. ${ }^{3}$

Benzer bir şekilde, 17. yüzyıldan itibaren egemen sınıf olma yolunda ilerleyen burjuvazinin çıkarlarına denk düşecek şekilde Descartes de, feodal dünya görüşüne karşı öznenin bilinç yapısını, aklını ve şüpheciliğini hakikatin özü olarak sunmuştur. ${ }^{4}$ Descartes’e göre, varlık ancak özne tarafından algılanmaktaysa varlıktır ve düşünmemezlik edemeyen ruh bilginin özünü oluşturmaktadır. Varlığın bilgisi mekân, zaman ve toplumsal sınırlamalardan yalıtılmış soyut öznenin bilinç yapısına göre şekillenmekte ve öznelerin farklı ahlaki değerleri, seçimleri, sezgileri ve akıl yapıları gerçekliği göreli, parçalı ve çoklu kılmaktadır. Bu bağlamda, öznel idealizmin üzerine eğildiği konu varlık (ontoloji) değil, öznenin (ruhun) bilgiyi nasıl edindiği (epistemoloji) olmaktadır.

İkinci grupta yer alan ve temsilcileri arasinda Francis Bacon (1561-1626), Thomas Hobbes (1588-1679) ve John Locke'u (1632-1704) bulunduran ampiristler de dönemin benzer nesnel koşulları içinden "teolojiyi” değil "insanı" odak alan "burjuva felsefecileri”’ olarak ortaya çıkmışlar fakat bilginin kaynağını özne olarak değil varlık olarak sunmuşlardır. Bacon, bilginin kaynağı olarak duyulardan gelen verilerin (deney, gözlem, tümevarım, karşılaştırma) biricikliğine ve yanılmazlığına vurgu yapar ve doğa bilimlerini gerçek bilim olarak sunarken, Hobbes bu düşünceleri sistemli bir hale getirmiş ve tüm değişimlerin temelinin madde olduğunu vurgulamıştır. ${ }^{6}$ Bacon ve Hobbes'un

1 Ülker Öktem, “John Locke ve George Berkeley’in Kesin Bilgi Anlayış”, Ankara Üniversitesi Dil ve Tarih Coğrafya Fakültesi Dergisi, Cilt 43, No.2, s.135.

2 August Thalheimer, Diyalektik Materyalizme Giriş, İstanbul, Yordam Kitabevi, 2009, s.54.

3 Ibid., s.58.

4 Ibid., s.85.

5 Aydınlanma sürecinde bilginin kaynağına teolojiyi ve siyasi gücün kaynağına da monarşiyi koyan iktidar ilişkilerine karşı hegemonya ilişkileri geliştirmek isteyen burjuvazi, bilginin ve iktidar ilişkilerinin merkezine "aklı" ve "insanı" yerleştirmeye çalışmıştır.

6 Karl Marx ve Friedrich Engels, Felsefe İncelemeleri, Cem Ertuğrul (çev.), İstanbul, Yordam Kitap, 2009, s.114. 
ilkeleri ışığında, Locke da bilginin doğuştan olmadığını aksine, öznenin başlangıçta bir "tabula rasa" (boş levha) olduğunu savunmuştur. ${ }^{7}$ Buna göre, bilgi duyumlar aracıllğıyla oluşmakta ve deneylerle gelişmektedir. ${ }^{8}$ Öte yandan, deneyden kastedilen, bireye dolayımsız olarak yansıyan görüngülerdir. ${ }^{9}$ Henüz diyalektik anlayışın oluşmadığı ampiristlerde bu durum, Hegel'in altını çizdiği gibi, "an” içinde yaşanan ve rastlantılardan oluşan tikellerin tümel olarak sunulması sorununu doğurmuştur. ${ }^{10}$ Buna ek olarak, ampiristler içinde de metafizik öğeler tamamen terk edilmemiş ve dış deney ve iç deney olarak ikiye bölünen süreçte dış deneyin konusunu varlık, iç deneyin konusu ise ruh olarak açılanmıştır. ${ }^{11}$

İki grup açısından da bilgiye ulaşma açısından öne çıkan araçlar arasında önemli farklar bulunsa da, iki grup için de sezginin ve ruhun varlığı kritik olduğu için gruplar arası geçirgenlik hayli yüksek olmuştur. ${ }^{12}$ Örneğin, George Berkeley (1685-1753) bilincin merkezi durumunu, maddenin zihnin algısı dışında oluşamayacağını (maddenin zihin dışında bağımsız bir varlığı bulunmamaktadır, dolayısıyla, yerçekimini reddeden aşağı düşmez) ve maddenin, kaynağı Tanrı olan, fikirlerden oluştuğunu söyleyerek kurarken aynı zamanda maddi bir öze sahip olmayan maddenin duyular aracılı̆ğ ile algılanabileceğini savunmuştur. ${ }^{13}$ Gene, birinci grubun temsilcilerinden Rene Descartes' in (1596-1650) akılcılığı ile İngiliz ampiristlerden Hobbes, David Hume ve Locke’un deneyciliğinden (deneyim) etkilenen Immanuel Kant (1724-1804), bilginin kaynağının deney aracılı̆̆ı ile dış dünyadan elde edildiğini savunmuş ama deneyin olmasını sağlayanın aklın yapısı olduğunu iddia etmiştir. ${ }^{14}$ Başka bir deyişle, Kant’a göre, maddenin bilgisi ampirik yolla elde edilirken, bilginin düzenlenmesi akıl yoluyla gerçekleşecektir. ${ }^{15}$ Bununla birlikte, Kant’a göre, aklın kaynağı deneyle elde edilemez ve eşyanın yansıttığı göreli imgeler dışında madde anlaşılamaz. ${ }^{16}$ Özne, sahip olduğu bilinç, sezgisi ve ahlak iradesiyle maddenin görünümünü yorumlamaktadır (deneyüstü düşüncecilik) ve bu da bilgiyi insan zihnine göre göreli kılmaktadır. ${ }^{17}$ Kısacası, Berkeley'in aksine Kant, maddenin varlığını ve bu varlığın duyu yoluyla algılandığını kabul etmekte fakat gerçeğin (varlığın özünün) hiçbir zaman tam olarak bilinemeyeceğini ve bilginin görelilik ve çokluk üzerine kurulduğunu iddia etmektedir.

Hegel görünüm ile özün bir arada olduğunu söyleyerek Kant'ı eleştirmiş fakat nesnel gerçekliğe dünyevi düzlemdehiçbir zaman ulaşılamayacağını savunduğu ve gerçekliğin düşünsel olarak kurulduğunu iddia ettiği için idealizm içinde kalmıştır. ${ }^{18}$ Bununla birlikte, Hegel’in sistematikleştirdiği diyalektik ve nesnel idealizm yaklaşımları onu önceki idealistlerden ayrıştırmaktadır. Bu farklılıklara geçmeden önce, Hegel'de somutlaşan nesnel idealizmin dönemin nesnel koşulları açısından beklenmedik olmadığını vurgulamak gerekmektedir. Feodal modelin değişmez ve sonsuz görünen üstyapılarına büyük bir darbe indiren Fransız Devrimi, hem değişimin mutlak olduğunu göstermiş hem de feodalizmi besleyen metafizik öğelerin doğa bilimlerinde olduğu gibi toplumbilimlerinden ayrıştırılmalarının yolunu açmıştır. Bilimselliğin öne çıktığı fakat metafizik öğelerin varlıklarını azalarak da olsa devam ettirdiği (Almanya’nın

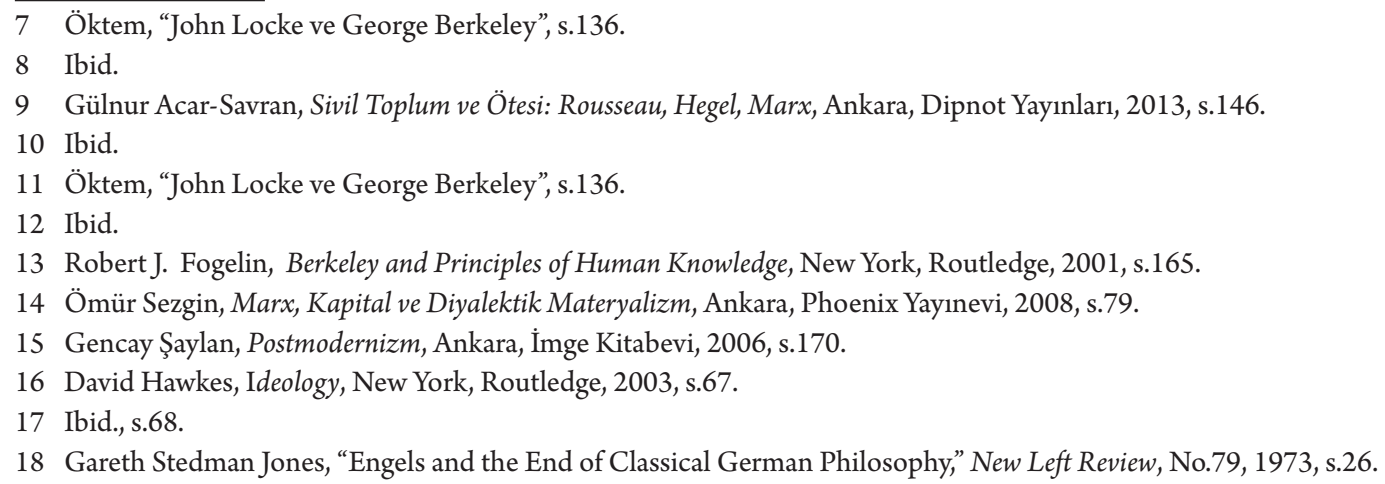


kapitalistleşme sürecine daha geç girmesi de göz önünde bulundurulursa) 19. yüzyılın başlarında Hegel, gerçeğin bilgisini mekân, zaman, tarih ve toplum koşullarından ayırarak (fetişletirerek) soyutlaştıran, özne ve nesne ilişkisini koparan, toplumsal ilişkileri sabit kabul eden (dogmalaştıran), karşıtların birbirini dışladığını iddia eden ve tarihi bütünlük ve süreklilik yerine, anlar ve kişilerden meydana gelen tekyönlü bir çizgi olarak ele alan (tarih tekerrür eder anlayışı) metafizik öğeleri bir kenara iterek diyalektiğin nesnel yasalarını sistemli bir bütünlük içinde geliştirmiştir. ${ }^{19}$

Diyalektik, en özlü biçimde, varlıkların-öznelerin mekân ve zaman uzamında birbirlerini sürekli koşullandırarak ve sürekli bir değişim döngüsüne tabi tutarak dönüştürmeleri olarak tanımlanabilir. Diyalektiğin en önemli üç yasası: niceliğin niteliğe ve niteliğin niceliğe dönüşümü, karşıtların iç içe geçmesi (çelişkilerin birliği) ve yadsımanın yadsınması, Hegel tarafından kategorize edilmiştir. ${ }^{20}$ Kısaca özetlenirse, bir arada bulunan çelişkilerin sınırlarına götürülmeleri halinde niteliksel olarak yeni varlıklara dönüşmesi, zıt görünen karşıt niteliklerin organik olarak birbirlerine bağlı olmaları ve birbirlerini yok etmek veya dışlamak yerine koşullandırarak dönüştürmeleri ve bu bağlamda, insan iradesinden bağımsız ilerleyen tarihsel süreçte çelişkilerin ilerlemeyi sağlayan ana itici motor olması, diyalektiğin ana tezleridir. ${ }^{21}$ Önceki diyalektik anlayışından farklı olarak, Hegel'in diyalektiğinde ilerleme tekyönlü değildir ve anlık olaylarla değil öncesi ve sonrasının bütünselliği içinde, insan iradesinden bağımsız olarak hareket eden bir süreçtir. Hegel’in dile getirdiği şekilde: "Herkes kendi zamanının çocuğudur, felsefe de aynı şekilde kendi zamanını düşüncede özetler.”22

Öte yandan, Hegel'in diyalektiği ana niteliklerini geliştirdiği noktada sona ermektedir, çünkü Hegelci diyalektikte, gerçekliğin tümüne yalnızca "Mutlak Fikir" (Tin, Geist, Idea) aracılığıyla evrimci bir süreçte ulaşılabildiği iddiası vardır. Mutlak Fikir, geçirdiği evrimci süreçlerden sonra kendi kendine dönmek üzere gelişmektedir. ${ }^{23}$ Buna göre, Mutlak Fikir önce maddeyi bilinçle soyutlar, daha sonra bu soyutlamaya yabancılaşarak kendi kendinin bilincinde olmaksızın doğa haline gelir ve son aşamada tekrar kendi bilincine ulaşır. ${ }^{24}$ Dolayısıyla, Mutlak Fikir, tam anlamıyla "kendi kendine dönünceye kadar, tarih içinde işlenip arınır.”25 Gerçekliğin zihinsel olarak kurulduğu bu süreçte, insan da karşılıklı etkileşimle sistematik olarak bir yandan gerçeklik tarafından şekillenirken, diğer taraftan bu gerçekliği şekillendirmektedir. ${ }^{26}$ Bilincin kendiliğinden kendisine ulaştı̆ğ tez-antitez-sentez döngüsünde, maddi koşullarda herhangi bir değişimin yaşanmasına gerek kalmaksızın (devrimlere veya isyanlara gerek duyulmadan) insanlar (köleler, serfler, vs.) özgürleşeceklerdir. Bu bağlamda, Hegelci felsefede birey, kendiliğinden birincil hale gelmekte ve kurtuluşa yönelik toplumsal hareketler anlamlarını yitirerek yerlerini bireylerin göreli gerçekliklerine bırakmaktadırlar.

Mutlak Fikir, bireyden başlayarak özgürlügünü aile, sivil toplum ve en nihayetinde rasyonel olan devlette gerçekleştirmektedir. ${ }^{27}$ Zaten Hegel'in “Gerçek olan her şey ussaldır ve ussal olan her şey

19 Thalheimer, “Diyalektik Materyalizme Giriş”, s.114; Sezgin, Marx, Kapital ve Diyalektik Materyalizm, s.15.

20 Sezgin, Marx, Kapital ve Diyalektik Materyalizm, s.64.

21 Bertell Ollman, Yabancılaşma: Marx’ın Kapitalist Toplumdaki İnsan Anlayışı, Ayşsegül Kars (çev.), İstanbul, Yordam Kitabevi, 2012, s.105.

22 Friedrich G. W. Hegel, Hukuk Felsefesinin Prensipleri, Cenap Karakaya (çev.), İstanbul, Sosyal Yayınlar, 1991, s.30.

23 Friedrich Engels, Ludwig Feuerbach ve Klasik Alman Felsefesinin Sonu, Sevim Belli (çev.), Ankara, Sol Yayınları, 1979 , s.50.

24 Friedrich G. W. Hegel, Tüze Felsefesi, Aziz Yardımlı (çev.), İstanbul, İdea Yayınevi, 2006, s.14-18; Hegel, Hukuk Felsefesinin Prensipleri, s.9.

25 Engels, Ludwig Feuerbach, s.50.

26 Peter Berger ve Stanley Pullberg, "Reification and the Sociological Critique of Consciousness", New Left Review, No.35, 1966, s.57.

27 Hegel, Hukuk Felsefesinin Prensipleri, s.15. 
gerçektir." ${ }^{28}$ cümlesinden hareket edildiğinde, bireylerden (örf ve adetler tarafindan şekillendirilen) kurulan devletin halkın kendi kendisinin bilincine ulaşmış en yüksek formu olarak anlaşıldı̆̆ı ortaya çıkmaktadır. ${ }^{29}$ Hegelci anlamda birey, ancak devletin vatandaşı olması halinde bilinci "kendiliğinde ve kendisi için” rasyonel hale gelecek ve gerçek özgürlüğe ve ahlaka sahip olabilecektir. ${ }^{30} \mathrm{Bu}$ bağlamda birey ve devlet birbirleriyle özdeşleştirilirken ilerlemenin belirleyici unsuru olarak da "ahlak fikrinin gerçekliği” ve "usun imgesi ve gerçekliği”" olarak devlet öne çıkartılmaktadır. Devletin bütünlügünü sürdürecek yönetim kademesi ise mutlak ahlaklılık mertebesine yükselmiş sınıflara yüklenmektedir. Bu bağlamda gerçekten de zamanının çocuğu olan Hegel'in yönetim kademesine uygun gördügü sınıf burjuvazidir. ${ }^{32}$

Sonuç olarak, Hegel'in nesnel idealizminde bilinç-madde tartışmasının bilinç kısmında kalmaktadır. Hegel'de diyalektik süreci sağlayan bilinç-madde (doğa) etkileşimi ve değişimi değil, salt düşüncenin kendisidir. Marx’ın belirtmiş olduğu gibi; "Sonuç, katıksız düşüncenin diyalektiğidir." Tüm bu bilgilerin ışığında, Hegel'in felsefesi diyalektik yöntemi kullanması bakımından devrimci ve nesnel ama bunları metafizik-tinsel öğelerle açıkladığı için idealisttir.

\section{Nesnel İdealizm ve Sezgisel Materyalizmden Diyalektik Materyalizme}

Hegelci anlayışın devrimci tarafını savunanlar ile idealist kanatta kalıp tutucu yanını savunanlar arasındaki tartışmaların süregittiği bir dönemde, Ludwig Feuerbach "Hıristiyanlığın Özü” (1841) isimli kitabıyla bir anda ivmenin materyalizme kaymasına yol açmıştır. Feuerbach'ın temel tezi, varlığın düşüncenin ürünü olmayıp, düşüncenin maddenin ürünü olduğu ve duyu ötesinde bir bilginin olmadığıdır. ${ }^{34} \mathrm{Bu}$ teziyle, Feuerbach kendisinden önceki (Engels' in betimlemesiyle) "utangaç materyalistlerin" üzerindeki örtüyü çekip almış ve tinsellikle tıkanmış Hegelci idealistlerin pasını atmışıı.

Ancak ne var ki, Feuerbach'ın devrimci materyalizmi, özellikle diyalekt yöntemin çözümlemelerden çıkartılmasıyla toplumsal alana geçtiği anda sona ermiştir. Feuerbach tarafından, tarih, mekân, zaman ve toplumdan kopartılarak, salt maddenin yansımaları ile açıklanmaya çalışılan soyut ve genelleştirilmiş insan etkinlikleri idealizmle harmanlanmış "sezgisel bir materyalizmden" ${ }^{35}$ öteye geçememiş ve tek tek bireylerin başta ahlak olmak üzere güdüsel amaçlarına bağlanmış bir toplum anlayışı ile sonuçlanmıştır. Üstelik Hegel gibi kendi tarihinin çocuğu olan ama Hegel'den farklı olarak altı materyalist üstü idealist olan Feuerbach, bireyi ve ahlakı tam da o günün kapitalist toplumuna uygun bir şekilde tarif etmiştir. ${ }^{36}$ Feuerbach'ın gerçek dünyanın koşullarından yalıtılmış bir şekilde sunduğu soyut ahlak kuramına göre, toplumdaki her bireyin kendi mutluluğu ve faydası peşinde koşması ve herkesin birbirine sevgi ile bağlanması sonucunda sorunlar çözülecektir. Sonuç olarak, Feuerbach'ın sezgisel materyalizminin ya da Feuerbach'ın idealizminin ulaştığı nokta "burjuva toplumu içindeki ayrı ayrı bireylerin görüş tarzıdır." ${ }^{37}$

28 Ibid., s.29.

29 Ibid.,s.16.

30 Ibid.,s.18.

31 Friedrich Engels, Ailenin, Özel Mülkiyetin ve Devletin Kökeni, Kenan Somer (çev.), Ankara, Sol Yayınları, 2010, s.199.

32 Hegel, Hukuk Felsefesinin Prensipleri, s.12. Çalışmalarının ilk zamanlarında Hegel’in yönetim kademesine uygun gördüğü sinif aristokrasidir.

33 Karl Marx, Felsefe Yaziları, Ahmet Fethi (çev.), İstanbul, Hil Yayın, 2009, s.81.

34 Thalheimer, "Diyalektik Materyalizme Giriş”, s.91.

35 Karl Marx ve Friedrich Engels, Alman İdeolojisi, Sevim Belli (çev.), Ankara, Sol Yayınları, 2010, s.27.

36 Marx ve Engels, Felsefe Incelemeleri, s.51-53.

37 Ibid., s.81. 
Karl Marx ve Friedrich Engels diyalektik materyalizmi geliştirirken hem Hegel'in tarihsel diyalektik yöntemi ve hem de Feuerbach'ın materyalizminden etkilenmiş fakat birincisinin yalıtılmış düşünce yaratılarını ve teolojik temellerini ikincisinin de görünüm ile özü özdeş kabul eden mekanik, durağan ve bireyci unsurlarını ayıklayarak madde ve düşünce etkileşiminin genel yasalarını (bilim) ortaya çıkartmışlardır.

Diyalektik materyalizmegöre, düşünce ve varlıkaynı olmadıkları gibi ayrı da değildirler. Düşünce ve varlık bir bütünün parçasıdırlar fakat diyalektik materyalizmde; "pratik, fikirlere göre açıklanmaz, fikirlerin oluşumu maddi pratiklere göre açıklanır." ${ }^{38}$ Bununla birlikte, diyalektik materyalizmde somut gerçekliğin düşünceye dolaysız olarak yansıdığı fikri de kabul görmez. ${ }^{39}$ Görünüm ile özün aynı olması halinde zaten gereksiz hale gelecek olan bilimin (bu eleştiri pozitivist kuramları da kapsar) temel amacı, düşünce ile varlık arasındaki koşullandırma ilişkisini bulmaktır. ${ }^{40}$ Bu bağlamda, insanlar gerçekliğe ilişkin fikirleri kavramlarla ifade etmekle birlikte, Hegel'in savunduğunun aksine kavramlar gerçekliğin kendileri de değildirler. ${ }^{41}$ Hegelcilere göre, insanlar gerçeklerin tersyüz olarak algılamaması için fikirlere (ideoloji) üç şekilde başkaldırılmalıdır: "insanlara yanılsamaları değiştirip, yerine insanın özüne uygun düşen düşüncelere koymayı öğretmek; insanlara yanılsamalar karşı eleştirici bir tutum almayı öğretmek; insanlara yanılsamaları kafalarından atmalarını öğretmek.”22 Oysa Marx ve Engels'e göre eleştiri (kavramların eleştirisi, bilgi-iktidar ilişkisi gibi, bilimin gereklerinden bir olmakla birlikte), kavramları mümkün kılan mevcut maddi (varlığa-ontolojiye ilişkin) koşullar (üretim biçimi, mülkiyet ilişkileri, toplumsal, tarihsel koşullar) hakkında olmalıdır. Zaten kavramlar ile gerçekliğin evrimi birebir paralel gitmemektedir. ${ }^{43}$ Maddi üretim araçlarını elinde bulunduran egemen sınıf, düşünsel üretim araçlarını da elinde tutmaktadır. ${ }^{44}$ Dolayısıyla, maddi ilişkilerin koşullandırmasıyla ortaya çıkan fikirler ve kavramları değişmez ve evrensel olarak göstermek ve ortak çıkar olarak sunmak üretim ilişkilerinin istenilen şekilde devam etmesini isteyen egemen sınıfın amaçlarındandır. Bu nedenle, bilimsel eleştirinin amacı, "teorik lafebeliği”" yaparak varlığı görüntüden, nedeni sonuçtan ayırmak değil, "görüntülerin arkasındaki gerçek ilişkileri”"46 ortaya çıkartmak ve değişimin ancak koşulların değişimi ile gerçekleşeceğini göstermektir. Marx’a göre, amaç, filozofların yaptığı gibi dünyayı farklı şekillerde yorumlamak değil, onu değiştirmek olmalıdır. ${ }^{47}$

Marx ve Engels, Hegelci idealistleri laf kalabalığı ve tutuculuk yapmakla suçlarken Feuerbach materyalizmine de ağır eleştiriler yöneltmişlerdir. Buna göre, görünüm ile özü bir tutan ve diyalektik dönüşümleri hesaba katmayan mekanik materyalistlerin toplumsal değişimleri açıklaması mümkün değildir. Üstelik kaba materyalizmin iddia ettiğinin aksine insanlar dünyaya boş bir kâğıt olarak gelmedikleri gibi, toplumlar da bireylerin iyi ahlak anlayışlarının yansıması olarak şekillenmemektedir. Diyalektik materyalizme göre, toplumsal yaşamın maddi temeli ve bireylerin doğayla ve birbirleriyle ilişkileri, her kuşağa öncüllerinden devredilmekte ve onların yaşam koşullarını belirlemektedir. ${ }^{48}$

38 Marx ve Engels, Alman İdeolojisi, s.68.

39 Sezgin, Marx, Kapital ve Diyalektik Materyalizm, s.18.

40 Bertell Ollman, Diyalektik Soruşturmalar, Cenk Saraçoğlu (çev.), İstanbul, Yordam Kitabevi, 2008, s.128.

41 Sezgin, Marx, Kapital ve Diyalektik Materyalizm, s.18.

42 Marx ve Engels, Alman İdeolojisi, s.31.

43 Sezgin, Marx, Kapital ve Diyalektik Materyalizm, s.18.

44 Marx ve Engels, Alman İdeolojisi, s.76.

45 Ibid.,s.71.

46 Sezgin, Marx, Kapital ve Diyalektik Materyalizm, s.19.

47 Karl Marx ve Friedrich Engels, Politika ve Felsefe, Tektaş Ağaoğlu (çev.), İstanbul, Belge Yayınları, 2011, s.16.

48 Allen W. Wood, Karl Marx, New York, Routledge, 2004, s.109. 
Bununla birlikte, bu belirlenim öznenin edilgen bir koşullandırma ilişkisine girmesi ile oluşmamaktadır. Marx’ın belirttiği gibi, "İnsanlar kendi tarihlerini kendileri yaparlar fakat kendi keyiflerine göre, kendi seçtikleri koşullar içinde yapamazlar, geçmişten kalan maddi koşullar içinde yaparlar." ${ }^{39}$ Diyalektik materyalizmde, bahsi geçen maddi koşulların temeli tarihsel bir süreç sonucunda ortaya çıkan ve toplumsal ilişkileri koşullandıran maddi üretim biçimi, üretim ilişkileri ve buna bağlı olarak ortaya çıkan sınıflar arasında yaşanan çatışmalardır.

Diyalektik materyalizme göre, tarihsel süreç içerisinde "bireylerin iradesinden bağımsız" \$0 olarak gelişen üretim biçimi ve üretici güçler arasındaki ilişkiler (altyapı), hukuk, devlet, din, sanat, felsefe gibi toplumsal, siyasal ve düşünsel (üstyapı) yaşam süreçlerini koşullandırmaktadır. ${ }^{51}$ Örneğin, Protestan Reformu, Kilise'nin ondalık vergisinden kurtulmak isteyen köylüler ile Kilise topraklarını ele geçirmeyi amaçlayan üst sınıfın (Kilise'nin mülksüzleştirilmesi) ortaklaştığı noktadan yükselirken, sanayi kapitalizmi 16. yüzyılda İngiltere'de ortak toprak mülkiyetini ortadan kaldıran çitleme hareketi sonrasında toprağa erişimleri kesilen kırsal kesimin şehirlere akın etmeleriyle ortaya çıkan ucuz işgücü desteğiyle gelişmiştir. ${ }^{52}$ Engels' in belirttiği gibi, diyalektik materyalizm de ortaya çıktığı döneminin toplumsal dönüşümleri (Fransız Devrimi, Napolyon savaşları, Avrupa'daki 1830 ayaklanmaları ve 1848 devrimleri) ve doğa bilimlerindeki buluşları (hücrenin ve yapısının keşfi, enerjinin dönüşümünün bulunuşu ve Darwin'in evrim teorisi $)^{53}$ sayesinde düşünce ve varlık arasındaki bağlantıları ve genel hareket yasalarını bulabilmiştir. En nihayetinde, diyalektik materyalizm de kendisini mümkün kılan nesnel koşulların ürünüdür.

Öte yandan, sanayi devrimi, toplumsal devrimler ve Aydınlanma dönemi koşulları altında sistemleşmesi bakımından tarihsel olan diyalektik materyalizmin, bilimsel bir düşünce biçimi ve araştırma yaklaşımı olarak açıklama gücü sadece kendi dönemi ile sınırlı kalmamıştır. Diyalektik materyalizm, değişimin ana yönelimlerini, çelişkilerin birlikteliğini ve üretim ilişkileri içinde ortaya çıkan sınıfsal karşıtlıkları, incelemesini yaptığı tarihsel süreçlerin kendi koşulları içinde açılamaya çalışmaktadır. Örneğin, Hindistan'daki kast sisteminin nasıl ortaya çıtığı ve dini olarak desteklendiği, diyalektik materyalizmin sistemli bir araştırma yaklaşımı olarak ortaya çıktığı kapitalist dönemin üretim ilişkileri bağlamında değil, ken di döneminin köle ekonomisi koşulları-ilişkileri ve bu ilişkilerin eğilimini belirlediği devlet, hukuk, ideoloji ve kültür bağlamında incelenmektedir. Benzer şekilde, günümüzde ortaya çıkan ekolojik, siyasal, toplumsal, ekonomik sorunlar ile bölgesel çatışmalar, iç savaş, terörizm, jeopolitik konuşlanmalar, göç hareketleri, otoriterleşme veya ırkçllı-mezhepçilik gibi zamanla nedene dönüşen semptomların araştırılmasında, diyalektik materyalizm, kapitalist üretim biçiminin içsel çelişkilerini (sermaye birikimi-kar oranlarının azalma eğilimi ve emek-sermaye çelişkileri) ve bu çelişkilerin eğilimini belirlediği yapısal kriz ve reformist düzenlemeler sürecini (örneğin esnek birikim

49 Karl Marx, Louis Bonaparte' in 18 Brumaire'i, Sevim Belli (çev.), Ankara, Sol Yayınları, 1976, s.13.

50 İdealist felsefe temelli olan yaklaşımların ortak hareket noktası bağımsız, rasyonel ve soyut bireydir. Bu bireyin hareketlerini etkileyen unsurların başında mekân ve zaman sınırlamalarından bağımsız olarak kişinin değişmez ve evrensel (çıkarlarını maksimize etmek için savaşan veya işbirliği yapan) doğası gelir. Bu verili doğa özelliklerine kişinin rasyonel, ahlaki ve özgür seçimleri eklenir.

51 Marx ve Engels, Felsefe İncelemeleri, s.91. Diyalektik materyalizmin ekonomik indirmecilikle suçlanması üzerine Engels şu yanıtı vermiştir: "Maddeci tarih görüşüne göre, tarihin belirleyici etmeni, son belirlemede, gerçek yaşamın üretimi ve yeniden üretimidir. Ne Marx ne de ben, bunun ötesinde bir şey söylemedik. Bundan sonra biri kalkar da, bu önermeye iktisadi etmen tek belirleyici etmendir dedirtecek kadar işkence ederse, onu, boş, soyut, saçma bir tümce durumuna düşürür.” Ibid., s.168.

52 Silvia Federici, Caliban ve Cadı: Kadınlar, Beden ve İlksel Birikim, Öznur Karakaş (çev.), İstanbul, Otonom Yayıncılık, 2004, s.102-107.

53 Friedrich Engels, Ludwig Feuerbach ve Klasik Alman Felsefesinin Sonu, Sevim Belli (çev.), Ankara, Sol Yayınları, 1979, s.53-54; Jones, "Engels and the End of Classical German Philosophy," s.24. 
modeline-neoliberalizm modeline geçiş ve bunun üstyapısal yansımaları-dönüşümleri) toplumların özgün ve değişen koşulları ışığında incelemektedir. Diyalektik materyalizmin dışlandığı tarihüstü bir araştırma yaklaşımının odaklanacağı unsurlar ise bu eğilimleri ortaya çıkartan ekonomik-toplumsal ilişkiler yerine, kendi kökenlerinden-nedenlerinden koparılarak gizemleştirilmiş ve fetişleştirilmiş kültür-ideoloji olmaktadır. Sonuç olarak diyalektik materyalizm, kendisini sistemleştiren tarihsel dönemin gelişmişlik düzeyi sınırlarını toplumsallık ve tarihsellik yaklaşımı bakımından aşmakta ve gerçekliğin bilgisine ulaşmada kapsamlı bir bilimsel analiz imkânı sağlamaktadır.

Özetle, diyalektik materyalizmde insanların varlıklarını belirleyen bilinçleri değil, bilinçlerini belirleyen toplumsal varlıklarıdır ve bunun son kertede belirleyicisi maddi yaşamın üretim biçimi ve üretici güçler (sınıflar) arasındaki çatışmalı ilişkidir. ${ }^{54}$ Fakat insanlar gerçekliği bu ilişkiler üzerinden değil tersyüz olmuş halleriyle, yani siyasi, hukuki, toplumsal ve düşünsel yansımaları ile görürler. $\mathrm{Bu}$ bağlamda, başlangıçta dış ve iç saldırılara karşı savunma amaçlı ve toplumun gelişmesindeki aşamaya bağlı olarak kurulan devlet organizması, belirli bir sınıfın egemenliğini üstün kıldığı ölçüde bağımsızlaşır ve kendisine ekonomik ve sınıfsal temelini görünmez kılacak yeni bir ideoloji yaratır. ${ }^{55}$ Üretim ilişkilerine ilişkin olanlar yasa şeklini alarak hukuksal olarak ifade edilmek zorunda olduğundan, hukuk ifadesini bulduğu siyasi ve ekonomik ilişkilerden öteye geçerek özerk bir görüntü taşımaya başlar. ${ }^{56}$

\section{Diyalektik Materyalizmden Nesnel İdealizm ve Felsefeye Dönüş: Eleştirel, Yorumsamacı ve Yapısalcı Kuramlar}

Modernitenin kavramlarından uzaklaşmaya başlamak, diyalektik materyalizmden tamamen kopmamakla birlikte yönünü felsefeye çevirmek ve maddi temellerinden ayrıştırılmış epistemolojiye odaklanmak, 1920’ler sonrası bilimsel çalışmaların ana eğilimini oluşturmuştur. Anderson’a göre Batılı Marksistler öncülügündeki felsefeye dönüşün ana nedenleri, 1917 Bolşevik devrimi sonrası kıta Avrupası'nda art arda gözlenen işçi sınıf kalkışmalarının yenilgiyle sonuçlanıp faşizmin zafer kazanması, 1945 sonrası Fordist düzenleme biçiminin altın çağında istikrarlı parlamenter demokrasilerin ortaya çıkması (devrim yerine kapitalizmle uzlaşan reformist sol siyasi partilerin de yardımıyla) ve tüketim toplumları ortamında emeğin sermayenin alt kümesi haline gelmesidir. ${ }^{57}$ Bunlara ek olarak, materyalist anlayışa uzak olan burjuva aydınlarıyla başlayan yakın temas (özellikle faşist-ırkçı yönetimler ve savaş sebebiyle Amerika'ya yerleşenler) ile oluşan kısmi uzlaşı, Marksist temelli düşünürlerin Hegelci felsefeye ve Hegel öncesi idealist yaklaşımlara doğru kaymalarına yardımcı olmuştur.

Kendi içinde bütünlüklü bir fikir birliği oluşturmamakla birlikte, 1930’larda Max Horkheimer' in birleştiriciliğinde somutlaşan ve etrafına Thedor W. Adorno, Herbert Marcuse, Walter Benjamin, Friedrich Pollock (daha sonraki kuşaktan Alfred Schmidt, Jürgen Habermas, Claus Offe) gibi düşünürleri toplayan Frankfurt Okulu veya daha genel bir ifadeyle eleştirel kuramlar, Hegel'in özne-nesne özdeşlik ve Kant'ın bilinemezciliği ile göreliliğini yeniden formüle etmişler ve Friedrich W. Nietzsche, Max Weber, Sigmund Freud ve Erich Fromm'un çalışmalarılyla sentezlemişlerdir. ${ }^{58}$

54 Marx ve Engels, Felsefe İncelemeleri, s.92.

55 Engels, Ludwig Feuerbach ve Klasik Alman Felsefesinin Sonu, s.63.

56 Ibid., s.64.

57 Ibid., s.61.

58 Leon Bailey, Critical Theory and Sociology of Knowledge: A Comparative Study in the Theory of Ideology, New York, Peter Lang, 1996, s.6. 
Eleştirel kuram, diyalektiği bir kenara bırakmamakla birlikte tarihin ilerleyici motorunun merkezine özneyi yerleştirmiştir. Başka bir deyişle, Hegel'in diyalektik anlayışındaki "Mutlak Fikir" yerini "bireye" bırakmıştır. ${ }^{59} \mathrm{Bu}$ bireycilik ve dolayısıyla farklı bilinç düzeyleri anlayışı ister istemez bilginin göreliliğine ve oradan yola çıkarak da inceleme alanının öznenin psikanalizine (örneğin; faşizmin nedenini otoriter kişilik oluşumuyla açıklamak), aile düzenine, kültürel geçmişine (bilimin geleneksel kültürü bozduğu iddiasıyla), ideolojik yaklaşımına (örneğin; bireyin bilgi-iktidarçıkar ilişkileri ve iktidarın ideolojik tahakkümü altında nasıl konumlandığı), kişisel faaliyetlerine (niyetlerine) ve kişinin özgür iradesiyle yaptığı iddia edilen bireysel seçimlerine (örneğin; siyasi, ekonomik ve kimliksel konumlanışı) yöneltilmesine sebep olmuştur. Bireyin bilincine indirgenen toplum anlayışı içinde, eleştirel kuramlar, Aydınlanmaya ait olan (aynı zamanda Hegel'e) rasyonalite/ akılcılık kavramını da eleştiriye tabi tutmuşlardır. Örneğin Nietzsche'nin insan doğasının kötülügüne vurgu yaparak açıkladığı "yaratıcı yıkıcılık" ve "aklın araçsallığı" kavramlarının da etkisiyle, Horkheimer ve Adorno aklın ve bilimin bireyin özgürleşme sürecinde "araçsal" ${ }^{60}$ bir rol oynadığını ama ulaşılan noktanın faşizm olduğu iddia ederek aydınlanmaya karşı eleştirel bir duruş geliştirmişlerdir. ${ }^{61}$

Sonuç olarak, eleştirel kuramcıların çalışmaları, gerçekliğin bilgisine ulaşmada maddi temelleri değil, bireylerin öznel algılarını temel almış ve "üstyapının epistemolojisine yoğunlaşmıştır." ${ }^{2}$ Birey esaslı toplum anlayışını temel alan ve pratik ile siyasetten (bilimin toplumsal-politik sorumluluğunun aksine) uzakta durmaya aşırı özen göstererek "salt teoriye ve kültüre odaklanan eleştirel kuramlar,"63 postmodernist kuramlara giden yolu döşemiş, fakat her şeye rağmen henüz Aydınlanma değerlerinden, nesnel bir gerçekliğin varlı̆ğ iddiasından (nesnel idealizm), tarihsel/toplumsal analizlerden ve diyalektik çözümlemelerden tam anlamıyla uzaklaşmamışlardır. Bu kırılma esas olarak 1970’lerin ikinci yarısından itibaren postmodernist kuramların sosyal ve siyaset bilimlerinde hâkimiyetlerini ilan etmesiyle başlayacaktır. Öteyandan, postmodernizme giden yolun taşlarını, eleştirel kuramkadaryorumsamacılarve yapısalcılar da döşemiştir. Örneğin, Berkeley’in felsefesine (öznel idealizm) yakın duran yorumsamacılar özne-nesne ayrılmazlı̆̆ı içinde bireyin öznel algılarını, bilinç düzeyini, iradesini ve "özgür" seçimlerini araştırmalarının başlıca konusu haline getirmişlerdir. Bireyin iradesini her türlü tarihsel, toplumsal, ekonomik ve siyasal koşulun önüne koyan ve birey dışındaki nesnel gerçekliği reddeden yorumsamacı kuramlar, gerçekliğin anlaşılabilmesi için dilde sözcüklere işlenen anlamların incelenmesi ve metinlerin yorumlanması gerektiğini savunmuşlardır. ${ }^{64} \mathrm{Bu}$ bağlamda yorumsamacılar, olguları açıklama, birbirine bağlama, sonuçları genelleştirme ve öngörü sağlama gibi bilimin temel işlevlerinin sosyal bilimler için geçerli olmadığını iddia etmiş ve yapılması gerekenin, farklı bireylerin bir araya gelmesiyle kurulan tarihsel, toplumsal, siyasal yapıların düzensizliğini "anlamak" olduğunu söylemişlerdir. ${ }^{65}$

59 Göran Thernborn, “The Frankfurt School”, New Left Review, No.63, 1970, s.77.

60 Horkheimer öznel akıl (araçsal) ve nesnel akıl (amaçsal) ayrımı yapar ve eleştirilerini, toplumu totaliterliğe ve tahakküm ilişkilerine mahkûm kıldığını iddia ettiği araçsal akla yöneltir. Marcuse ise benzer bir sınıflandırmayla endüstriyel toplumun akıl biçimi olarak "teknik akılı" öne çıkartır ve onun aracılığıyla insanların teknolojik egemenlik altına girdiğini ve tek boyutlu bir toplum yarattığını iddia eder. Cem K. Olgun, "Frankfurt Okulu Düşünürlerinde Akıl Kavramı", Sosyoloji Notları, No.1, 2007, s.23-25.

61 Thernborn, “The Frankfurt School," s.83. İlerleyen dönemde Karl Popper'in öğrencisi olan Paul Feyerabend, epistemolojik anarşizmi savunarak akılcılığın bilimden tamamen dışlanması gerektiğini iddia edecek ("Akla Veda" çalışmasıyla) ve gerçekliğe ulaşmada bilimin tekçi bir yöntem olarak kullanılmasının totalitarizmle sonuçlanacağını savunacaktır. Paul Feyerabend, Against Method, Londra, New Left Books, 1975.

62 Atilla Güney, "Postmodern İdeoloji, Siyasetten Arındırma Süreci ve Türkiye'de Siyaset”, Ankara Üniversitesi SBF Dergisi, Cilt 61, No.1, 2006, s.176.

63 Hans Heinz Holz, Frankfurt Okulu Eleştirisi, Olcay Geridönmez (çev.), İstanbul, Evrensel Basım Yayın, 2012, s.12-16.

64 Levent Köker, İki Farklı Siyaset: Bilgi Teorisi Siyaset Bilimi İlişkiler Açısından Pozitivizm ve Eleştirel Teori, Ankara, Dipnot Yayınları, 2008, s.82.

65 Ibid., s.121. 
Yapısalcı yaklaşımlar ise, Ferdinand de Saussure'nin dilin kapsayıcılığı, ses yapılarının ilişkiselliği ve sözcüklerin anlam birliğine ilişkin yaptığı dilbilim çalışmaları ile Antonio Gramsci’nin sınıflar arasında rızaya dayalı kurulan ve ideolojinin aktif bir bileşen olarak yer aldığı "tarihsel ittifak" (hegemonya) tezinden aldıkları ilhamla, 1960'lardan 1970 ortalarına kadar sosyal bilimlerde başat akım olarak öne çıkmışlardır. ${ }^{66}$ Aslında postmodernist kuramların temel kavramlarını oluşturacak olan yapısalcılık, 1950'lilerde kıta Avrupa'sının aksine materyalist bir geçmişe sahip olmayan ve Fordist üretim modeli içinde dönemin Amerikan orta sınıfının refah artışını temel alarak kapitalizm övgüsü yapan Amerikan sosyoloji çevresinde geliştirilmiş ve 1960'larda başta Fransa olmak üzere Avrupa'ya yayılmış ve daha sonra tekrar ABD'ye ihraç edilmiştir. ${ }^{67}$ Henüz kârların düşme eğilimine girmediği kapitalizmin altın çağında, Fordist birikim şekli, Keynesyen refah devleti modeli, Bretton Woods uluslararası para sistemi, Soğuk Savaş konjonktürüne bağlı bloksal ayrışmalar, küresel-bölgesel boyutlu örgütlenmeler-kurallaşmalar ve olağanüstü teknolojik gelişmeler döneminin ürünü olan yapısalcı yaklaşımlar, diyalektik materyalizmin süreci yapının önüne koyan anlayışını tersine çevirerek genel yapının öncelliğini savunmuşlardır. ${ }^{68}$ Öznenin son derece edilgen bir şekilde sadece taşıyıcısı olduğu bu kendinden devinimli, tarihsiz, toplum dışı, mekâna ve zamana ait olmayan yapının (dolayısıyla değiştirilemez) asli kurucuları (gerçekliği inşa eden) ise ideoloji, iktidar, siyaset, hegemonya, söylem, toplumsal roller, cinsiyet, gelenekler, kültür, dilsel yapılar, metin ve estetik gibi epistemolojiye ait unsurlardır. Özetle, yapısalcılıkta bilinç ve özne dışlanırken, gerçekliği oluşturan dış gerçeklik de nesnel bir süreç yerine çelişkili bir şekilde kolektif bir öznesiz öznellikler (yapının kendisini özne kılan) toplamına eşitlenmektedir.

Son olarak, başta yapısalcılar olmak üzere diğer okulların da benimsediği şekliyle araştırmaların temeline yerleştirilen muğlak epistemolojik söylemlerin (kuramsal zayıfllğı) sözde-ilişkisiz bilimsel analojilerle açıklanması ve teknik terimler arkasına saklanması (Sokal ve Bricmont'un ifadeleriyle; “bulanık söylemlere bilimsel nitelik cilası atmak"), 1950'lerden 1970’lerin ortalarına kadar sosyal ve beşeri bilimlerde hâkim yaklaşım olmuştur. ${ }^{69}$

\section{Öznel İdealizmin Dönüşü ve Diyalektiğin Ölümü: Postmodernist Kuramlar}

Postmodernizm, bütünsel veya homojen bir kuram olmaktan ziyade bir eğilimi yansıtmaktadır. 1980’li yıllarda yükselişe geçen ve postmodernizm genel başlığı altında toplanabilecek postmarksist ve postyapısalcı gibi "yenilenme" iddiası taşıyan yaklaşımlar bu eğilim içinde oluşmuşlardır. ${ }^{70}$ Postmodernist kuramlar, 1970'lerin ikinci yarısından itibaren idealizmin yüceltilmesinde ve metafiziğe yaklaşacak şekilde gerisine düşülmesinde bayrağı öncüllerinden (eleştirel kuramlar, yorumsamacılar, yapısalcılar, pragmatistler vb.) devralmışlardır. Aslında Michel Foucault, Jacques Derrida, Jean-

66 Ali Murat Özdemir, Sözün Mülkiyeti: Hukukun Ekonomi Politĭgi, Ankara, Dipnot Yayınları, 2008, s.44.

67 Aijaz Ahmad, “On Post Modernism," The Marxist, Cilt XXVII, No.1,Ocak-Mart 2011, s.2.

68 Özdemir, Sözün Mülkiyeti, s.51.

69 Alan Sokal ve Jean Bricmont, Son Moda Saçmalar: Postmodern Aydınların Bilimi İstismar Etmesi, Barış Gönülşen (çev.), İstanbul, Alfa Bilim, 2011, s.33. Örnek olarak, Jacques Lacan'nın bir matematik dalı olan topoloji ile ruh hastalıklarını açılaması ve Julia Kristeva’nın matematiksel kümeler ile dilbilim karşılaştırması gösterilebilir. Ibid., s.40-62.

70 Postmodernizmin önde gelen isimlerinden olan Michel Foucault, Jacques Derrida, Jean-Francois Lyotard, Daniel Bell, Jean Baudrillard, Gilles Deleuze, Felix Guattari, Ernesto Laclau ve Chantal Mouffe'nin aynı kuram içinde değerlendirilmesi zorlama bir çıkarım olmakla birlikte, postmodernizmin temel referanslarını ve terminolojisini geliştirmiş olmaları ve çözümlemelerinin benzer bir eğilim taşıması sebepleriyle, bu isimlerin çalışmaları postmodernist kuramının kapsayıcılığı içinde değerlendirmek yanlış olmayacaktır. 
Francois Lyotard, Daniel Bell, Jean Baudrillard, Gilles Deleuze, Felix Guattari, Ernesto Laclau ve Chantal Mouffe veya daha geriye gidilirse Adorno, Althusser, Marcuse, Horkheimer gibi isimlerin ortak esinlenme noktası "19. yüzyılın en önde gelen 'anti-Aydınlanmacı' düşünürü" Nietzsche'dir. ${ }^{71}$ Nietzsche'nin Aydınlanma döneminin kazanımları olan akılcılığa, eşitliğe, özgürlüğe, gelişmeye ve diyalektik analize karşı eleştirel duruşu, her bireye özgü olarak var olduğunu iddia ettiği "yaşam enerjisi”72 üzerinden bilginin yorumsal, göreli (gerçekliğin çokluluğu) ve geçici olduğu tezi ve son olarak, "tarihin akışının bir mantığı olmadığı"73 varsayımı üzerinden ilerleme anlayışını reddetmesi, postmodernist ve onun öncülleri olan kuramlara ilham vermiştir.

Başlarındaki post ekine rağmen bu kuramlar bir kopuşu değil (çünkü postmodernist kuramlar da kendi zamanlarının çocuklarıdır) devamlılık içinde kırılmayı yansıtırlar. Başka bir deyişle, postmodernist kuramlar, 1970’lerin başında yapısal bir krizle karşı karşıya kalan kapitalizmin neoliberalizm olarak tabir edilen ve Aydınlanma değerleri (eşitlik, özgürlük, rasyonellik, bilimsellik, nedensellik), Fordist birikim şekli (düşünsel izdüşümü: bütünlük, homojenlik, sınıfsallık, örgütlülük, işlevselcilik), Keynesyen refah devleti modeli (düşünsel izdüşümü: toplumsallık, vatandaşlık) ve Bretton Woods uluslararası para sistemini (düşünsel izdüşümü: kuralcılık, ulusalcılık, mekânsal sınırlama, öngörülebilirlik) tasfiye eden kapsamlı bir yeniden yapılanma veya yenilenme modelinin düşünsel yansımalarıdır. Postmodernist teoriler, "eleştirel olma iddiasına rağmen ironik bir biçimde sürecin yayılışına katkı koyan ve tahakkümü onaylayan" "74 bir anlayış içinde kalmışlar ve gerçekliğin tanımlanmasına dair pratikle örtüşen bir kavramlar seti veya teori birikimi geliştirememişlerdir. Bunun aksine, postmodernizmin öne çıkan kavramları neoklasik iktisadın teorik ve pratikteki gelişimiyle paralel bir seyir izlemiştir. Örneğin, Post-Fordist modelde bir önceki döneme ait olan büyük firmalar-kitle pazarı yerini küçük şirketler (taşeronlar)-parçalı pazara bıraktıkça, artık değeri arttırmak amacıyla sosyal devlet gerekleri kaldırıldıkça, emeğin milli gelirden aldığı pay düşürüldükçe ve finans piyasalarının önündeki tüm engeller (ulusal ve küresel) kaldırıldıkça ve neoliberal yapılanma "emeğin örgütlü eyleme geçmediği "itirazsız birikim" sürecini kurguladıkça"75 ve örgütlü-sınıfsal haklar parçalandıkça, bunların yansımaları postmodernizmin kavramlarında karşılık bulmuştur. Başka bir deyişle, kapitalist üretim ilişkilerinde ortaya çıkan gerçeklikteki yeni tersyüzlüklerin ideolojik yansımaları postmodernizmde vücut bulmuştur. Postmodernist kuramların fetişleştirdiği kavramlar tersyüzlüğe paralel olarak şöyle olmuştur: "baskıcı" devlet, "özgürleştirici” sivil toplum, farklılık, ötekilik, öznellik, negatif özgürlük, bölünmüşlük, tikelcilik, heterojenlik, örgütsüzlük, kuralsızlık (deregülasyon), yönetişim, mekân ve zaman sınırsızlığı, küreselleşme-yerelleşme, ana ve tesadüfe dayalı tarihsellik, öngörülememezlik, çoklu gerçeklikler ve tüketim toplumu.

Öncül kuramların eklektizminden oluşmakla birlikte, bunlardan farklı olarak postmodernist kuramlar, gerçeklerin tersyüz olarak algılanmasına neden olduğu iddia edilen yanılsamaları yok etmek veya eleştirmek amacını ve kaygısını taşımamış, aksine yanılsamaları gerçekliğin referansı olarak ele almışlardır. Öte yandan, bu gerçeklik referansı ile yanılsamalara eleştiri getirmemeye

71 Şaylan, Postmodernizm, s.119.

72 Nietzsche'ye göre, yaşam enerjisinin iyicil ve göreli olarak düzenli-yüksek hali, "üstün-seçkin” bireyler olan aristokratlardan çıkmaktadır. Yaşam enerjisi düşük olan sıradan halka Aydınlanma döneminde olduğu gibi eşitlik, özgürlük verilir ve bilgi-bilim temel olursa "Aydınlanma projesindeki iyimser öncüllerin aksine yabancılaşma, anarşi, vahşet ve acımasızlık da egemen olacaktır”. Ibid., s.120.

73 Ibid.

74 Göksu Uğurlu, “Eylemsizliğin Eylem Hali: Post-Kolonyal Çalışmalar ve Uluslararası Hukuk”, Ali Murat Özdemir (der.), Emperyalizmin Hayaletleri: Küresel Düzenlemenin Bugünü, Ankara, İmge Yayınevi, 2013, s.216.

75 Kansu Yıldırım, “Kapitalizmin Yönetimsel Restorasyonu: Krizler ve Yönetişim Mantığı”, Özdemir (der.), Emperyalizmin Hayaletleri, s.171; Erdoğan, “Küresel Pazarın Küresel İdeolojisi”, s.8. 
özen gösterilmiş ve hem bilim hem de toplumsal alanda atıf yapılabilecek bir gerçekliğin varlı̆ğ toptan reddedilmiştir. ${ }^{76}$ Başka bir deyişle, postmodernistler, Terry Eagleton'un "başıboş metafizik" veya "yeni model idealizm" 77 olarak tanımladığı radikal bir epistemolojik kuşkuculuk içinde doğa yasalarının en temel ilkeleri de dâhil (yerçekimini de katarak) olmak üzere her türlü bilginin (bilimsel ilerlemenin gerçekliğini de yadsıyarak) kurgulanmış olduğunu iddia etmektedirler. ${ }^{78}$ Postmodernizmde, gerçeklik, artık toplumsal ilişkileri yansıtmaları bağlamında söylem, anlatı, dil veya kültürde aranmaz, tam tersine, bu sayılanlar artık "bizzat gerçekliği kuran yapılar olarak tanımlanır”. ${ }^{79}$ Kısacası, postmodernizme göre; dilin, söylemin, anlatının veya kültürün dışında hiçbir dışsal hakikat yoktur. Bu bağlamda, bilinç mi madde mi tartışması postmodernizmde daha hiç gündeme gelmeden maddenin reddedilmesi ile sona ermektedir. Bununla birlikte, 21. yüzyılın ulaştığı bilimsel gelişmeler bakımından maddeyi-gerçekliği kuranın salt bilinç olduğu anlayışı da ileri sürülememektedir. Bunun yerine, idealist yaklaşım sınırları içinde kalan ama neredeyse tamamen edilgenleştirilmiş ve tarihten, mekândan, toplumsal ve ekonomik ilişkilerden tamamen bağımsız olarak (koşullandırma, etkileşim, değişim ve nedensellik ilişkisinden tamamen yalıtılmış) bilincinin veya postmodernizm açısından daha doğru bir tanımlamayla bilinçaltının; gerçekliği kuran yapılarca (dil, kültür, söylem ve anlatım) şekillendirildiği temelsiz bir birey anlayışı geliştirilmiştir. ${ }^{80}$ $\mathrm{Bu}$ bağlamda, postmodernizmde birey yapıyı kuran değil sadece taşıyandır. ${ }^{81}$ Toplumsal ilişkiler "öznesiz ilişkiler pratiği”" içinde kendiliğinden yapı içinde oluşmakta ve kendinden devinimli her zaman ve her yerde olan iktidar-güç ağları tarafından gerçekleştirilmektedir. Bu tanımsız güç ağlarına karşı mücadele, ise gene yapı içerisinde çoklu hakikatlerin (farklılıkların) taşıyıcıları arasında (ötekiler) gerçekleşecek diyaloglar (farkındalığa ulaşma), mikro direnişler veya sivil toplum kuruluşları nezdinde bir araya gelen gruplar arası temsiller yoluyla mümkün olabilecektir.

\section{Değerlendirme-Sonuç}

Varlığın gerçekliğine ilişkin bilginin ne olduğu ve buna nasıl ulaşılacağına ilişkin sorun yüzyıllar boyunca insanoğlunun kafasını kurcalamış ve özellikle Aydınlanma döneminden başlayarak bilimsel bilgi üretimine dair birçok çalışmanın ana konusu olmuştur. Günümüzde sosyal bilimler alanında birçok farklı kuram içinden türevlenen sayısız çalışma bulunmaktadır. Bu çalışmalar farkında olarak

76 Sokal ve Bricmont, Son Moda Saçmalar, s.210. Öncüllerinin aksine postmodernistler için bilgi-iktidar ilişkisini sorgulamak ve toplumdaki güç ilişkilerini ortaya çıkartmaya çalışmak artık gereksiz bir faaliyettir. Erdoğan, "Küresel Pazarın Küresel İdeolojisi”, s.16. Gerçeği ortaya çıkartmaya çalışan ve bu süreçte toplumsal ilişkileri sorgulamayı amaç edinen "bilimsel sorumluluk" yerini andaki verili durumu sorgusuz sualsiz gerçek olarak ele alan "bilimsel aklamaya" bırakmıştır.

77 Terry Eagleton, Postmodernizmin Yanılsamaları, Mehmet Küçük (çev.), İstanbul, Ayrıntı Yayınları, 1999, s.27.

78 Bilimsel bilgiye radikal bir kuşkuculuk ile yaklaşan, bilimi bir "anlatı" veya "söylence" olarak değerlendiren ve dışsal bir dünyanın var olduğuna ilişkin bilgileri "dogma” olarak kabul eden postmodernizm, ironik bir şekilde tezlerini kanıtlamak amacıyla doğa bilimlerinden analojiler yapmakta veya doğrudan kanıt olarak öne sürmektedir. Sokal ve Bricmont, Son Moda Saçmalar, s.20.

79 Güney, “Postmodern İdeoloji”, s.181.

80 Yapısalcılıktan farklı olarak postmodernizmde birey, yapının içindeki farklı alt kültürlerin (etnik, din, mezhep, medeniyet, cinsiyet, yaş veya yöresel değerler) etkisi altında şekillenmiştir. Geçmiş ve geleceğin olmadığı her şeyin "an" içinde gerçekleştiği ortamda birey kendi kendine oluşmuş bireysel bir kültürün taşıyıcısıdır. Bireyin kendisinin bile sürekli ve bütünsel bir gerçeklik anlayışı yoktur. Bu anlamda, öznel gerçekliklerin çokluğu nesnel bir gerçekliğin olmasını engellemekte ve hem bireylerin kendi içinde hem de bireyler arasında oluşan çoklu hakikatler, bütünsel ve bilimsel bir gerçeklik açıklamasını imkânsız kılmaktadır.

81 Ibid.,s.182.

82 Güney, “Postmodern İdeoloji”, s.189. 
veya olmayarak bilimsel bilginin kaynağı açısından İdealist ve Materyalist olmak üzere iki ana paradigma ve bilimsel bilgiye ulaşma yöntemi olarak da diyalektik ve diyalektik dışı yaklaşımlar temelinde gelişmektedir. Bu iki paradigma içinden yapılan çalışmaların tarihteki ana kırılma noktası, Hegel'in diyalektik yaklaşımı sistemleştirdiği Aydınlanma dönemidir. Diyalektik yaklaşım salt teknik bir yöntemin ötesinde bilginin nitelik açısından bilimsel olup olmadığını belirleyen ana unsurdur. Diyalektik yaklaşımda olayın mekândaki görüntüsü, andaki sabitliği ve varlık-özne özdeşliğinin/ bağımsızlı̆̆ının ötesine geçilir ve varlıkların-öznelerin mekân ve zaman uzamında birbirlerini koşullandırarak, etkileşime sokarak ve sürekli bir değişim döngüsüne tabi tutarak dönüştürmeleri esas alınır. Hegelci diyalektikte dönüştürücü unsur, teolojik bir temeli de olan "Mutlak Fikir" (kendi kendine yabancilaşıp süreç içinde kendi bilincine varan "ruh") olur ve bireyin bilinci kendiliğinden birincil hale gelir. Diyalektik materyalizmde ise değişimin kaynağı mevcut maddi koşullar temelinde gerçekleşir ve bireyin bilinci mevcut koşulların (üretim biçimi, mülkiyet ilişkileri, sınıfsal çatışmalar, toplumsal ve tarihsel koşullar) etkileşimiyle oluşan toplumsal varlığına göre şekillenir. Dolayısıyla, Hegelci diyalektikte gerçeklik tanımı, birey (bilinç) temelli, göreli, parçalı ve çoklu iken diyalektik materyalizmde gerçeklik tanımı maddi koşullar temelli bütünsel, ilişkisel, toplumsal ve tarihseldir.

Diyalektik yaklaşım öncesinde bilgi üretiminde öne çıan öznel idealizmin temel iddiası, zamanın ve mekânın koşullandırmasından muaf olan öznenin gerçekliğin bilgisine doğuştan gelen zihinsel sezgisi-bilinciyle ile ulaştığı ve ortaya çıkan bilginin toplumsal bir varlığ olmayan bireyin göreli ahlakı ve aklına uygun olarak parçalı, durağan ve çok sayıda hakikatten oluşmasıdır. Aynı dönemde materyalizme yakın sayılabilecek ampiristlerin iddiası ise, bilginin kaynağının salt varlığın kendisi olduğu ve bilginin maddenin dolaysız yansıyan görüntüsünden duyular aracılığıyla deneylerle elde edilebilmesidir. Bu bağlamda, ampiristlere göre gerçeklik "an" içinde rastlantısal olarak kurulan parçaların toplamıdır. İdealist ve ampiristlerin yanı sıra her iki yaklaşımın da sentezini yapan Berkeley ve Kant (bilinemezcilik) gibi düşünürler de bu dönemde etkili olmuş fakat her iki paradigmanın sınırlılıkları içinde kalmışlardır.

Hegelci diyalektik ile gelişen nesnel idealizm, nesnel koşullar altında özne ve maddenin birbirini sürekli olarak koşullandırdığını-dönüşüme uğrattığını iddia ederek bilgi üretimini nesnel alana çekmiş fakat dünyevi koşullarda gerçekliğe hiçbir zaman ulaşılamayacağını ve gerçekliğin de ancak düşünsel (bireyin bilincinde) olarak kurulduğunu savunarak idealist paradigma içinde yer almıştır. Marx’n geliştirdiği diyalektik materyalizm ise maddeyi özneden bağımsız tutan ve görüntü ile bilgiyi eşitleyen ampiristler ile altı materyalist üstü idealist olan Feurbach'ın sezgisel materyalizmini bir kenara itmiştir. Diyalektik materyalizm, maddenin bilinçten önce geldiğini, özneyi koşullandırdığını ve karşılıklı etkileşimin (çelişkilerin birliği dâhilinde) dönüşüm sürecini çalıştırdığını iddia etmiştir. Diyalektik materyalizme göre, maddi koşullar göreli olmadığı gibi, maddi koşullarla etkileşime giren-güdülenen özne de edilgen veya taşıyıcı değil, koşullar bağlamında kendi tarihini yapabilen aktif bir bireydir.

Aydınlanma döneminde gittikçe hâkim hale gelen kapitalist üretim biçimi ve burjuvazi, feodal değerlere-felsefesine (dışsal bir gerçeklik tanımayan, değişme, rasyonaliteye, nedenselliğe, öznelliğe, şüpheciliğe karşı duran ve bireyi edilgen bir kader taşıyıcısı olarak tanımlayan), hukukuna, sınıfsal düzenlemelerine ve kurumlarına karşı bilimin, rasyonalitenin, bireyin, laikliğin, siyaset-hukuktoplumsal değişimin öne çıkartıldığı düşünce akımlarına destek vermiştir. Bu dönemde özellikle öznelnesnel idealizm burjuvazinin düşünsel alanını oluştururken, dönemin göreli düşünsel özgürlüğü, devrim hareketleri ve bilimsel keşifleri içinde diyalektik materyalizm de kendisine alan bulmuştur. 
Kapitalist üretim biçimi ve onun siyasi mekanizmalarının, hukuki modelinin ve toplumsal kontrol aygıtlarının başat hale geldiği 20. yüzyılın başlarından itibaren mevcut birikim modelini korumak ve sürdürmek amacıyla sermaye sınıfının öncülügünde düşünsel alanda aklın/rasyonalitenin giderek dışlandığı ve yerine sezgisel bilinç, ahlak, gelenek ve kültür gibi unsurların eklendiği yeni yaklaşımlar gelişmeye başlamıştır. Bu yaklaşımlar içinde öne çıan eleştirel kuramlar, Hegelci diyalektikteki teolojik temelli "Mutlak Fikir" yerine "birey-özneyi” koyarken (dolayısıyla, araştırma odağı nesnel koşullardan psikanalize, aile düzenine, kültürel geçmişe, ideolojik güdülenmeye, kişisel tercihlere ve bireysel seçimlere yönelmiştir), yorumsamacılar kendisini dilde yansıtan bireyin iradesi dışındaki nesnel gerçekliğin anlaşılamayacağını söyleyerek diyalektik anlayışın dışına çıkmışlardır. 1960'lardan 1970 ortalarına kadar sosyal bilimlerde hâkim olan yapısalcılık ise diyalektik yaklaşımın temelinde yer alan "süreç" yerine kendinden devinimli, tarihsiz, toplum dışı, mekân ve zaman sınırlamasına tabi olmayan bir "yapı” anlayışı geliştirmiş ve öznenin bu yapının salt edilgen bir taşıyıcısı olduğunu iddia etmiştir.

Kapitalizmin içsel çelişkilerinin bir sonucu olarak 1970’lerden itibaren kapitalist birikim modelinde başlayan yapısal kriz, ABD öncülügünndeki neoliberal restorasyon projesinin devreye sokulmasına ve küresel olarak iktisattan siyasete, hukuktan toplumsal ilişkilere, askeri yapılanmalardan bilime kadar her alanda kapsayıcı bir dönüşümün gerçekleşmesine yol açmıştır. Neoliberalizmin tasfiye ettiği kapsamlı-bütünsel modeller (kitlesel pazar-tüketim anlayışı, sosyal-hukuk devleti, örgütlü-sınıfsal haklar gibi) yerlerini zaman ve mekândan muaf parçalı (kuralsızlık, taşeronlaşma, tikelcilik, yerelleşme üzerinden küreselleşme, yönetişim) pratik ve kavramlara bırakmıştır. Bu sürecin sosyal bilimlerdeki izdüşümü olarak postmodernist akım, radikal bir epistemolojik kuşkuculuk içinde öncelikle her türlü bütünsel teoriyi ve gerçekliği reddetmiş ve maddi gerçekliğin yokluğunda tüm bilginin kurgulanmış olduğunu iddia etmiştir. Postmodernistler bir taraftan dışsal gerçekliği ("an" içinde oluşan çoklu hakikatler dışında) reddederken diğer taraftan bilinci de yadsıarak bireyi yönlendirenin tarih, mekân, toplumsal varlık, ekonomi, siyaset ve diğer gerçeğe ilişkin ilişki türleri değil dil, söylem, anlatı, kültür ve yalıtılmış kimliğe dayalı bilinçaltı olduğunu iddia etmişlerdir. Aklı yadsımak, nesnel bir gerçekliği kabul etmemek, bireyi özne olmaktan çıkararak edilgen bir taşıyıı konumuna sokmak, mekân-zaman ve toplumsal süreçleri tanımamak (diyalektik dışı kalmak) bakımından postmodernist akım bilimden ziyade felsefeye yakın bir anlayış içinde kalmıştır.

Sonuç olarak, idealist-materyalist ayrımı ve diyalektik anlayışa sahip olup olmamak bakımından günümüzde sosyal bilimlerin geldiği aşama veya içinde olduğu genel eğilim, diyalektiğin giderek dışlandığı öznel idealizm ile Aydınlanma öncesi felsefesine doğru gidiştir. Gerçeği nedenlerinden, iç çelişkilerinden, tarihsel süreçten ve toplumsallıktan ayırarak tecrit etmek, küçük parçalara bölmek, fetişleştirilmiş kavramlarla yeniden tanımlamak ve herhangi bir sonuca varmadan soyut önermelerin sonsuz çokluğuna bırakmak, bilimin temel işlevleri olan açıklama, nedenselleştirme, ilişkileri tutarlı bir bütünsellik içinde analiz etme ve öngörü oluşturma gerekliliklerinin yerine getirilmesine engel olacaktır. 


\section{Kaynakça}

Acar-Savran. Gülnur, Sivil Toplum ve Ötesi: Rousseau, Hegel, Marx, Ankara, Dipnot Yayınları, 2013.

Ahmad, Aijaz. "On Post Modernism," The Marxist, Cilt XXVII, No.1, Ocak-Mart 2011, s.2-37.

Bailey, Leon. Critical Theory and Sociology of Knowledge: A Comparative Study in the Theory of Ideology, New York, Peter Lang, 1996.

Berger, Peter ve Stanley Pullberg. "Reification and the Sociological Critique of Consciousness", New Left Review, No.35, 1966, s.56-71.

Eagleton, Terry. Postmodernizmin Yanılsamaları, Mehmet Küçük (çev.), İstanbul, Ayrıntı Yayınları, 1999.

Engels, Friedrich. Ailenin, Özel Mülkiyetin ve Devletin Kökeni, Kenan Somer (çev.), Ankara, Sol Yayınları, 2010.

Engels, Friedrich. Ludwig Feuerbach ve Klasik Alman Felsefesinin Sonu, Sevim Belli (çev.), Ankara, Sol Yayınları, 1979.

Erdoğan, İrfan. "Küresel Pazarın Küresel İdeolojisi: Postmodernizm," Bilim ve Ütopya, No.217, Temmuz 2012, s.7-16.

Federici, Silvia. Caliban ve Cadı: Kadınlar, Beden ve İlksel Birikim, Öznur Karakaş (çev.), İstanbul, Otonom Yayıncilik, 2004.

Feyerabend, Paul. Against Method, Londra, New Left Books, 1975.

Fogelin, Robert J. Berkeley and Principles of Human Knowledge, New York, Routledge, 2001.

Güney, Atilla. "Postmodern İdeoloji, Siyasetten Arındırma Süreci ve Türkiye’de Siyaset," Ankara Üniversitesi SBF Dergisi, Cilt 61, No.1, 2006, s.175-200.

Hawkes, David. Ideology, New York, Routledge, 2003.

Hegel, G. W. Friedrich. Tüze Felsefesi, Aziz Yardımlı (çev.), İstanbul, İdea Yayınevi, 2006.

Hegel, G. W. Friedrich. Hukuk Felsefesinin Prensipleri, Cenap Karakaya (çev.), İstanbul, Sosyal Yayınlar, 1991.

Holz, Hans Heinz. Frankfurt Okulu Eleştirisi, Olcay Geridönmez (çev.), İstanbul, Evrensel Basım Yayın, 2012.

Jones, Gareth Stedman. "Engels and the End of Classical German Philosophy," New Left Review, No.79, 1973, s. 17-36.

Koçer, Gökhan. "Küreselleşme ve Uluslararası İlişkilerin Geleceği”, Uluslararası İlişkiler Dergisi, Cilt 1, No.3, 2004, s.101-123.

Jovel Kovel. “Praksis Olarak Diyalektik," Bertell Olmann ve Tony Smith (der.), Yeni Yüzyılda Diyalektik, Şükrü Aşpagut (çev.), İstanbul, Yordam Kitap, 2011.

Köker, Levent. İki Farklı Siyaset: Bilgi Teorisi Siyaset Bilimi İlişkiler Açısından Pozitivizm ve Eleştirel Teori, Ankara, Dipnot Yayınları, 2008.

Marx, Karl. Louis Bonaparte' in 18 Brumaire'i, Sevim Belli (çev.), Ankara, Sol Yayınları, 1976.

Marx, Karl ve Friedrich Engels. Felsefe İncelemeleri, Cem Ertuğrul (çev.), İstanbul, Yordam Kitap, 2009.

Marx, Karl ve Friedrich Engels. Politika ve Felsefe, Tektaş Ağaoğlu (çev.), İstanbul, Belge Yayınları, 2011.

Marx, Karl ve Friedrich Engels. Alman İdeolojisi, Sevim Belli (çev.), Ankara, Sol Yayınları, 2010.

Marx, Karl. Felsefe Yazıları, Ahmet Fethi (çev.), İstanbul, Hil Yayın, 2009.

Olgun, Cem K. "Frankfurt Okulu Düşünürlerinde Akıl Kavramı," Sosyoloji Notları, No.1, Nisan 2007, s.22-30.

Ollman, Bertel. Diyalektik Soruşturmalar, Cenk Saraçoğlu (çev.), İstanbul, Yordam Kitabevi, 2008.

Ollman, Bertell. Yabancılaşma: Marx’ın Kapitalist Toplumdaki İnsan Anlayışı, Ayşegül Kars (çev.), İstanbul, Yordam Kitabevi, 2012.

Öktem, Ülker. “John Locke ve George Berkeley’ in Kesin Bilgi Anlayışı,” Ankara Üniversitesi Dil ve Tarih Coğrafya Fakültesi Dergisi, Cilt 43, No.2, 2003, s.133-149.

Özdemir, Ali Murat. Sözün Mülkiyeti: Hukukun Ekonomi Politiği, Ankara, Dipnot Yayınları, 2008. 
Sezgin, Ömür. Marx, Kapital ve Diyalektik Materyalizm, Ankara, Phoenix Yayınevi, 2008.

Sokal, Alan ve Jean Bricmont. Son Moda Saçmalar: Postmodern Aydınların Bilimi İstismar Etmesi, Barış Gönülşen (çev.), İstanbul, Alfa Bilim, 2011.

Şaylan, Gencay, Postmodernizm, Ankara, İmge Kitabevi, 2006.

Thalheimer, August. Diyalektik Materyalizme Giriş, İstanbul, Yordam Kitabevi, 2009.

Thernborn, Göran. “The Frankfurt School,” New Left Review, No.63, 1970, s.65-96.

Uğurlu, Göksu. “Eylemsizliğin Eylem Hali: Post-Kolonyal Çalışmalar ve Uluslararası Hukuk”, Ali Murat Özdemir (der.), Emperyalizmin Hayaletleri: Küresel Düzenlemenin Bugünü, Ankara, İmge Yayınevi, 2013.

Wood, Allen W. Karl Marx, New York, Routledge, 2004.

Yıldırım, Kansu. "Kapitalizmin Yönetimsel Restorasyonu: Krizler ve Yönetişim Mantı̆̆g", Ali Murat Özdemir (der.), Emperyalizmin Hayaletleri: Küresel Düzenlemenin Bugünü, Ankara, İmge Yayınevi, 2013. 